\title{
Trade and product innovations as sources for productivity increases: an empirical analysis
}

\author{
Frank A. G. den Butter · Jan L. Möhlmann • \\ Paul Wit
}

Published online: 23 September 2008

(c) The Author(s) 2008. This article is published with open access at Springerlink.com

\begin{abstract}
Increases in total factor productivity (TFP) are commonly associated with technological innovations measured by the stock of R\&D. Empirical evidence seems to corroborate this relationship. However, in trading countries like The Netherlands, productivity increases, even in industry, can also be the result of innovations in the way transactions are managed. These innovations reduce transaction costs and exploit the welfare gains from (further) international division of labour. Such innovations are only partly included in R\&D data. Consequently there is not much attention for these 'trade innovations' - as we label them-in policy. In an empirical analysis this paper compares the influence of trade innovations with the influence of the stock of R\&D on TFP in The Netherlands. The regression results show that in this country trade innovations are as important for TFP as technological innovations which directly affect the efficiency of production, which we label 'product innovations'.
\end{abstract}

Keywords R\&D - Innovation - Transaction costs · Total factor productivity

JEL Classifications $\mathrm{F} 10 \cdot \mathrm{F} 43 \cdot \mathrm{O} 47$

F. A. G. den Butter $(\bowtie)$

Department of Economics, Vrije Universiteit, De Boelelaan 1105, $1081 \mathrm{HV}$ Amsterdam, The Netherlands

e-mail: fbutter@feweb.vu.nl

\section{J. L. Möhlmann}

Department of Spatial Economics, Vrije Universiteit,

Amsterdam, The Netherlands

P. Wit

Algemene Rekenkamer (Netherlands Court of Audit),

The Hague, The Netherlands

\section{Introduction}

In modern growth theory productivity improvements are measured by the increase of total factor productivity (TFP). TFP forms the part in the increase of production in the production function that can not be explained by capital and labour inputs. Mostly innovations and technical change are thought of as contributors to TFP. Technical innovations are also the primary focus of the Lisbon Strategy. This strategy was agreed upon by the member states of the European Union (EU) in 2000 in order to make the EU "the most competitive and the most dynamic knowledgebased economy in the world" by 2010 . One of the methods of achieving this is by spending at least $3 \%$ of the income on research and development (R\&D). Empirical research on productivity growth has also focused mainly on $R \& D$ and human capital formation.

However, there exists an alternative factor that could explain productivity growth: transaction costs. Lowering these costs leads to further specialisation and division of labour and consequently to productivity growth. This study shows that innovations lowering transaction costs might even explain TFP better than R\&D stock does in The Netherlands. Although most economists recognise the importance of transaction costs, there is not much empirical evidence in the literature on the contribution of innovations that lower transaction costs (which we label trade innovations) to TFP. Data on R\&D only partially capture trade innovations and mainly measure innovations which directly enhance the efficiency of production (which we label product innovations). A reason for the lack of studies that explicitly study the contribution of trade innovations to TFP is that transaction costs and innovations lowering these costs are difficult to measure. This paper tries to deal with this measurement problem by using the 
difference in the growth of trade and the growth of output as a proxy for trade innovations (TI). The implicit assumption is that without trade innovations, the costs of trading would not decrease and the growth of trade would be equal to output growth. We use this proxy in order to answer the following research questions: (i) How much do trade innovations and R\&D contribute to TFP in The Netherlands? (ii) Are trade innovations contributing more to TFP than investments in R\&D in The Netherlands? (iii) Should innovations lowering transaction costs be incorporated in the Lisbon Strategy?

The structure of the paper is as follows. The next section shortly describes the concepts of TFP, R\&D expenditure and transactions costs from the perspectives of economic growth theory and transaction costs economics. It gives an overview of the existing empirical research on the impact of R\&D and human capital formation on economic growth and productivity. Moreover, some theoretical arguments are given for government intervention. Section 3 discusses the data used in the empirical analysis. The specification and the results of the empirical analysis are presented in Sect. 4. It focuses on The Netherlands because we expect trade innovations to play an important role in this country. The Netherlands is regarded as a 'nation of traders', where distribution, financing, marketing and services are important sectors in the economy (see e.g. WRR 2003; Van Dalen and Van Vuuren 2005). We conduct a regression analysis on time-series data for the 1950-1992 period.

Although the outcome of the regression results is mixed, it suggests that trade innovations have become more important for TFP than product innovations. Section 5 concludes and considers the implications of the analysis for the Lisbon Strategy. When trade innovations play a major role, which appears to be the case in The Netherlands, the exclusive focus of the Lisbon Strategy on R\&D expenditures is less warranted. The differences of orientation between EU countries as transaction economies are also an argument against the 'one size fits all' approach of the Lisbon Strategy.

\section{Innovation, growth and transaction costs}

\subsection{Total factor productivity and endogenous growth theory}

In modern growth theory productivity improvements are measured by the increase of TFP. It forms the part in the increase of output in the production function that can not be explained by capital and labour inputs, and covers many other and sometimes unobserved determinants of productivity. It also includes measurement errors and aggregation bias. Tinbergen (1942) introduced the concepts of TFP and efficiency and Solow (1957) provided a simple framework to measure TFP. In empirical studies on TFP it is often calculated by means of a growth accounting approach (see e.g. Timmer et al. 2003; Van Ark and De Jong 1996; Van Ark et al. 2002; Hulten 2000).

The neo-classical growth model developed by Solow and Swan forms the basis for the derivation of TFP. In this model technological progress is assumed to be exogenous and treated as 'manna from heaven'. In order to understand and measure the influence of the stock of R\&D on TFP, models were developed that endogenise technological progress and economic growth. An earlier strand to endogenous growth theory is the 'AK approach', according to which technological knowledge is intellectual capital, which can be lumped together with computers, crankshafts, and other forms of capital into a single aggregate $\mathrm{K}$ (see Aghion and Howitt 1998). Seminal models of endogenous growth theory are given by Lucas (1988), who incorporates human capital into the model and Romer (1986), in which the accumulation of knowledge is the primary reason for economic growth. An early empirical model were technical progress is endogenised through the stock of $R \& D$ is explained in Den Butter and Wollmer (1992, 1996).

\subsection{Empirical research on the determinants of growth}

Endogenous growth theories have formed the basis of numerous empirical studies aimed at explaining economic growth and TFP. This research mainly follows two lines. The first line builds on the model of Romer (1986) and focuses on R\&D. The second line explains growth through the accumulation of human capital and builds on the work of Lucas. As our empirical research is confined to the influence of R\&D on TFP, we will not discuss human capital explanations for economic growth any further, albeit our definition of trade innovations is much related to investments in human capital.

Empirical studies on the impact of R\&D on total output use cross-section, time series and panel data on the level of the country, the industry and the firm. A survey by Cameron (1998) shows that most empirical studies find a strong relationship between $\mathrm{R} \& \mathrm{D}$ capital and output. The elasticities range from 0.06 to 0.42 .

From a policy point of view the spillovers from investments in new technologies are important, as they are associated with positive externalities. It hinges on the assumption that technology only has to be developed once and can then be implemented by everyone without making the development costs. A survey by Canton (2002) shows that spillover effects (or indirect effects), are a major contributor to growth. On average, the indirect returns of $R \& D$ are 2.63 times the value of the direct returns of R\&D. 
With respect to the link between TFP growth and R\&D spillovers, Jacobs et al. (2002) use sectoral data for The Netherlands. They find an elasticity of TFP with respect to R\&D of $37 \%$ for R\&D conducted by the sector itself, of $15 \%$ for R\&D conducted by other sectors in The Netherlands, and of almost 3\% for R\&D by foreign sectors. Guellec and Van Pottlesberghe de le Potterie (2001) use panel data for 16 OECD countries and their estimates show that an increase of $1 \%$ in business $R \& D$, foreign $R \& D$ and public R\&D generates a productivity growth of respectively $0.13 \%, 0.44 \%$ and $0.17 \%$. These studies emphasise the importance of $R \& D$ spillovers since both domestic R\&D as well as foreign R\&D have a significant impact on productivity growth.

\subsection{Transaction costs economics and trade innovations}

The main argument of this paper is that besides product and process innovations resulting from technology oriented R\&D, innovations in trade can also lead to productivity growth. The theoretical basis for this is provided by the economics of transaction costs. It shows that lowering transaction costs will lead to further specialisation and division of labour, and therefore to productivity growth. When R\&D data would include efforts to reduce transaction costs, an empirical analysis of the influence of R\&D on productivity growth would automatically include the effect of trade innovations. However, efforts to foster trade innovations are, for a large part, excluded from data on R\&D.

The first author to use the term 'transaction costs' was Arrow (1969). He referred to transaction costs as the costs of running the economic system. A more detailed taxonomy of transaction costs is given by Williamson (1985). Williamson follows Arrow's definition and uses the economics of information as an important building block. He distinguishes between ex ante and ex post transaction costs. Drafting, negotiating and safeguarding an agreement are part of the ex ante transaction costs. The ex post transaction costs consist of the costs incurred when transactions drift out of alignment with requirements, the set up and running costs associated with the governance structures to which the disputes are referred, and the bonding costs of effecting secure commitments (Dietrich 1994).

Although Williamson (1985) focuses on the indirect costs of exchange, direct costs are also part of transaction costs. In this paper we define transaction costs as all costs market participants make in exchanging goods, services and ideas. This includes traditional costs of trade transactions, like transportation costs, taxes and tariffs, as well as more indirect costs. Examples of indirect costs are the costs of searching a potential trading partner, information costs about the reliability of the trading partner and the quality of the goods and services, the costs of negotiation and contracting, monitoring and enforcement costs, and also the costs of the legal infrastructure. Shortly said, transaction costs are all costs except the development and direct production costs.

In this vein North and Wallis (1994) make a distinction between transformation costs and transaction costs. Here, transformation costs are the costs of the land, labour, capital, and entrepreneurial skill required to physically transform inputs into outputs. Transaction costs are the costs of the land, labour, capital, and entrepreneurial skill required to transfer property rights from one person to another. A distinction between these costs is, however, difficult to make. They illustrate this by the following example. Hiring a foreman to supervise workers should be treated as a transaction cost, since it changes the property rights attached to the labour services by transferring the right to direct labour from the worker to the foreman, whereas in fact the foreman is typically treated as a cost of production.

\subsection{Transaction costs, trade innovations and productivity}

Lowering transaction costs increases productivity in two different ways. When transaction costs decrease, less resources are needed for making the same amount of transactions. These resources can be used for other purposes which increases total output. Secondly productivity is increased because the size of trade increases which allows for more specialisation. In the traditional trade theory, trade is viewed as an allocation problem where transaction costs play a minor role (for an overview of trade theories see Krugman and Obstfeld 1997). However, there are significant transaction costs involved in trading. These transaction costs, as specified above, have an important impact on the size of trade (Trefler 1995) and set a limit to specialisation and division of labour and therefore to productivity growth. Lowering these costs will thus enhance further specialisation and division of labour and consequently productivity growth (see Amable 2000). Herrendorf and Teixeira (2005) show in a theoretical exercise how barriers to international trade, which can be considered to bring about high transaction costs, negatively affect TFP.

Some examples of trade innovations are given in North (1997). He explores existing innovations that significantly lowered transaction costs and led to new production and exchange. Three important trade innovations are mentioned. The first is the development of institutions that permitted anonymous exchange to take place across space and time. Among these institutions were intercommunity credit markets, insurance markets, contracts for future 
delivery, and the bill of exchange. Merchants gradually evolved codes of conduct (Law Merchant). In the absence of state enforcement, the basis of enforcement lied in reputation damage. As markets grew, this reputation mechanism was insufficient, which led to the second major trade innovation: the assumption by the state of the protection and enforcement of property rights. The third innovation is the realisation of the gains from the modern revolution in science. Taking advantage of the 'marriage of science and technology' that led to new technology entailed an enormous reorganisation of economies to realise the potential gains of this technology. It is necessary to have control over quality in the lengthening production chain and to have a solution to the problems of increasingly costly principal-agent relationships. Therefore institutional and organisational restructuring is essential to gain from technology. As North (1991) states: declining costs of transacting brought about by the innovations of institutions played a key role in the process of growth. It nicely illustrates the interaction between technological progress and innovations that reduce transaction costs.

Our concept of trade innovations is somewhat related to what Jacobs (1999) has labelled 'transaction innovations'. In his view innovations do not only comprise product and process innovations, but also the mass customisation, i.e. the way products and services are sold. Examples are the distribution of pizzas and the leasing of cars and airplanes. In a similar vein Lynch (2007) considers investments in 'organisational innovation'. According to her empirical study of US businesses, investments in human capital, information technology, $\mathrm{R} \& \mathrm{D}$ and physical capital are complementary to organisational innovation. However, she does not separate the effects of organisational innovations from the effects of other inputs on productivity.

\subsection{The role of the government}

North and Wallis (1982) emphasise that the government has an important role in reducing transaction costs. Their argument is that the state should not only be concerned with income transfer activities, but that it should also devise a set of rules to reduce transaction costs of the economic system. This will foster economic growth and expand the tax base and therefore increase income available for transfers. The fundamental argument is that due to externalities, free rider problems and economies of scale, there are market failures which the government has to repair.

\subsection{Measuring transaction costs}

Although lowering transaction costs can contribute significantly to productivity growth, the empirical proof is scarce. That is because transaction costs are difficult to measure. Many types of transaction costs are unobservable and cannot be quantified, for example search costs and risks. North and Wallis (1986) use the size of the transaction sector as a proxy for the aggregate size of transaction costs in the economy. The fundamental problem in using this proxy is that, on the one hand, division of labour gives rise to more exchange and hence brings about more transactions and more transaction costs. And on the other hand, at the micro level it is desirable to minimise transaction costs. The rise of the transaction sector is exactly to serve that purpose (Wang 2003). Therefore using the size of the transaction sector as a measure for transaction costs can be misleading. This is especially true for a trading nation such as The Netherlands, which has skills and a tradition in keeping transaction costs low. A further problem here is to come to an operational definition of the transaction sector. For instance, production and value creation of multinationals is, in the statistics, allotted to the production sector, whereas for example in The Netherlands, a large part of the activities of the multinationals relate to the orchestrating function of their headquarters. In fact this can be regarded as value creation through transactions.

If innovations lowering transaction costs were correctly measured in $R \& D$ figures, there would be no need to use a proxy for trade innovations. But according to the definition of R\&D in the current system of national accounts (SNA93), many types of trade innovations are not considered R\&D. The SNA-93 definition states that research that leads to intangible assets is not considered to be R\&D. Following the Frascati Manual (OECD 2002), the international guideline for measuring $\mathrm{R} \& \mathrm{D}$, the main principle is that $R \& D$ leads either to pure knowledge creation or to the initial conception of a product or process innovation. The existence of exclusive ownership of knowledge is an important precondition for knowledge to comply with the general SNA definition of an asset (De Haan and Van Rooijen-Horsten 2004). The creation of general knowledge without exclusive ownership is thus not considered an R\&D activity. Remarkably, this definition is even at variance with the argument of innovation policy that knowledge creation from $R \& D$ brings about positive externalities due to incomplete excludability.

From the SNA definition of R\&D it follows that increasing knowledge about foreign markets is not included in R\&D figures. Neither are trade innovations of an institutional nature, such as the creation of a system of law.

It shows that a large part of research efforts which lead to innovations lowering transaction costs are not included in $R \& D$ figures. However, this does not mean that $R \& D$ figures do not measure any efforts to come to trade innovations at all. Some technological innovations included in $\mathrm{R} \& \mathrm{D}$ figures directly lead to lower transaction costs. The 
most obvious transaction costs that are lowered by technological innovations are transportation costs, for example by the creation of more efficient means of transportation. Another innovation which is partly driven by $R \& D$ and which has reduced transaction costs is the use of internet for communication purposes. So efforts to bring about trade innovations are partially measured in $R \& D$ figures. However, the above examples also show that trade innovations go far beyond the technological results from what is registered as R\&D. For example, a considerable part of reduction in transport costs can be associated with the use of world wide standards, such as the container, which is only to a minor extent the consequence of $R \& D$ expenditures. With respect to internet, network externalities and skills to use the appropriate software may even be more important than technical, $R \& D$ driven innovations.

For these reasons, this study uses an alternative proxy to measure trade innovations at the macro level. The proxy is based on the difference between the growth of trade and the growth of production. In this way we try to circumvent the problems of the proxy used by North and Wallis (1986) and acknowledge that trade innovations contribute to a reduction of transaction costs at the micro level, but probably not at the macro level. The basis of our proxy is the assumption that the limits to trade are caused by transaction costs. Trade innovations reduce transaction costs, leading to further specialisation and division of labour and consequently to an increase in trade. Here the amount of trade can be seen as a function of trade innovations and demand. Without trade innovations only the demand for trade changes due to an increase in production. In this case the growth of trade should be equal to the growth of production, assuming unit elasticity. Therefore we regard the difference between the growth of trade and the growth of production as a suitable measure for trade innovations, although we do acknowledge that our proxy is a very rough measure of the underlying concept. In order to bring our proxy of trade innovations in line with the stock of $\mathrm{R} \& \mathrm{D}$ which is used as an indicator for product innovations, we created a stock variable for trade innovations by making an index with the base year 1950 based on the differences in the growth rates of trade and production. The growth rate of this stock variable $\left(\mathrm{TI}_{t} / \mathrm{TI}_{t-1}\right)$ is defined as the difference in growth rates:

$\frac{\mathrm{TI}_{t}}{\mathrm{TI}_{t-1}}=1+0.5\left(\frac{\text { Import }_{t}}{\text { Import }_{t-1}}+\frac{\text { Export }_{t}}{\text { Export }_{t-1}}\right)-\frac{\mathrm{GDP}_{t}}{\mathrm{GDP}_{t-1}}$

Obviously using this indicator in estimating the contribution of trade innovations and R\&D to TFP has its limitations as well. In the first place, the proxy for trade innovations measures the effect of trade innovations on trade and specialisation. It does not measure the total amount of expenditures on trade innovations (which may be subjected to diminishing returns). Consequently, by using this proxy nothing can be said about the effectiveness of investing in trade innovations. Secondly, the problem of reverse causality between trade innovations and productivity growth exists. When productivity increases due to technological improvements, economic actors may become more willing to invest in trade innovations because of the limits on growth caused by transaction costs. Productivity growth can thus lead to more innovations in trade, just as innovations in trade can lead to productivity growth. Finally, it should be noticed that an accurate distinction between innovations in production and trade innovations can not be made. Although R\&D figures focus on innovations in production, they do, as mentioned before, partially measure trade innovations as well. When estimating the contribution of trade innovations and $R \& D$ to TFP simultaneously, the effect of some innovations in production that also lead to lower transaction costs is now picked up by trade innovations and is no longer attributed to R\&D. Therefore there might be some multicollinearity.

\subsection{Trade innovations and the Lisbon Strategy}

The Lisbon Strategy focuses on knowledge and research and development. One of the criteria of the Lisbon Strategy is that $3 \%$ of the GDP is invested in R\&D. However, as previously explained, innovations in trade can also generate economic growth. Investments in trade innovations should therefore also be included in the $3 \%$ criterion. Important policy issues for lowering transaction costs are education, infrastructure, better information and international co-operation. Some technological innovations do indeed contribute to a reduction of transaction costs. Examples are research in the transportation sector or research in the ICT sector. The latter decreases transaction costs through lower search and information costs. But a large part of innovations in trade remains unobserved and therefore unnoticed in policy. The Lisbon Strategy focuses on investments on $R \& D$ because these investments bring about large spillovers between countries so that the EUcountries collect welfare gains from each others investments in R\&D. Gelauff and Lejour (2006), using an applied general equilibrium model for the world economy, find large positive effects for the EU when its members would meet the target of $3 \%$ GDP. But trade innovations also benefit from positive externalities because trade innovations, by definition, benefit multiple parties since multiple parties are involved in trade. When someone decides to learn a foreign language to improve trading with the foreign country this benefits the person learning the language, as well as the foreign trading partners. Clearly there are positive externalities involved because only one person has to make the costs of learning a new language. These externalities are examples of network externalities. 


\section{Data}

In order to measure the influence of $R \& D$ and trade innovations on TFP we use time series data for the period 1950-1992 for The Netherlands. The proxy for trade innovations is constructed using annual real data on GDP, exports and imports from National Accounts statistics. Data on TFP and on the stock of R\&D for the 1950-1992 period are taken from Van Ark and De Jong (1996). All three variables are indexed using 1950 as the base year.

Van Ark and De Jong (1996) constructed the TFP data using the growth accounting approach. They assume an economy with constant returns to scale and with perfect markets. TFP is calculated by dividing the output growth by a weighted average of the growth of inputs where the compensation shares of the inputs are used as weights. Output is measured by GDP, capital input is measured by the non-residental capital stock and labour input is measured by the amount of hours worked. The GDP and the non-residental capital stock values are both converted to 1990 guilders.

The R\&D stock is calculated by Van Ark and De Jong (1996) using the perpetual inventory method (PIM). Investments in $\mathrm{R} \& \mathrm{D}(R \& D \exp )$ are assumed to last for 15 years and are then fully depreciated:

$R \& D$ stock $k_{t}=\sum_{i=0}^{15} R \& D \exp _{t-i}$

Van Ark and De Jong (1996) obtained data on R\&D expenditures from a study by Minne (1995). The R\&D expenditures are converted to 1990 guilders using the GDP deflator. Of course the above calculation of the stock of R\&D capital is somewhat arbitrary as one can think of other depreciation schemes-e.g. a graduate depreciation. However, the above specification is in line with vintage models of capital stock which also assume that the oldest vintages are scrapped according to a first in first out (FIFO) scheme.

Unfortunately no comparable data on TFP are available for a more recent period. Therefore our empirical analysis does not take developments after 1992 into account. Figure 1 shows the development of the annual growth rates of TFP, the stock of $R \& D$ and trade innovations. Growth rates are derived as the difference in the natural logarithm between two subsequent periods. The growth rate of trade innovations seems to follow the growth rate of productivity rather well. The growth rate of investments in R\&D is characterised by a strong negative trend until 1983. The graph also shows that there is a peak in growth of trade innovations in the year 1952. Because we are using time series data the amount of observations is limited and this outlier seriously affects the regression results. To get more

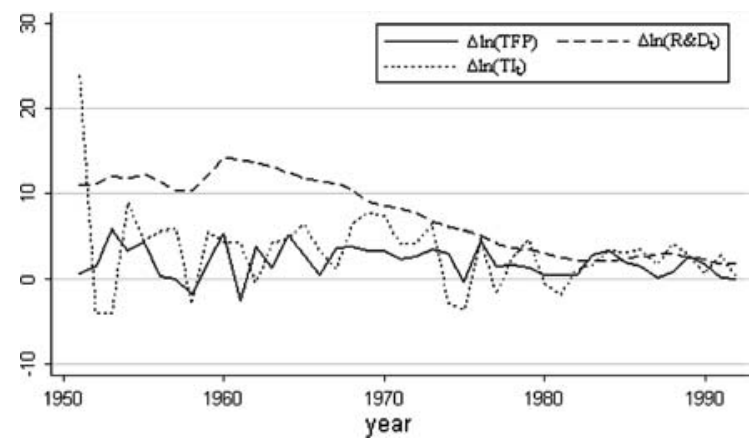

Fig. 1 Annual growth of TFP, R\&D and trade innovations in The Netherlands, in percentages

Table 1 Average annual growth of TFP, R\&D and trade innovations in The Netherlands between 1950 and 1992, in percentages

\begin{tabular}{lllrl}
\hline From & To & TFP & R\&D & TI \\
\hline 1950 & 1992 & 2.0 & 7.8 & 3.2 \\
1950 & 1970 & 2.3 & 12.3 & 4.7 \\
1971 & 1992 & 1.6 & 3.6 & 1.8 \\
1950 & 1955 & 3.2 & 12.3 & 6.0 \\
1956 & 1960 & 1.3 & 12.5 & 3.3 \\
1961 & 1965 & 3.3 & 13.6 & 3.8 \\
1966 & 1970 & 3.6 & 10.2 & 5.8 \\
1971 & 1975 & 2.2 & 6.7 & 1.1 \\
1976 & 1980 & 1.2 & 3.7 & 1.2 \\
1981 & 1985 & 2.2 & 2.3 & 2.3 \\
1986 & 1992 & 0.9 & 2.4 & 2.0 \\
\hline
\end{tabular}

plausible results the models will be estimated for the 19551992 period.

Table 1 summarises the data by giving average annual growth rates for various periods. The table shows that the growth of TFP is the highest in the period 1966-1970. During this period, the growth of trade innovations is also peaking. The growth rate of the stock of $R \& D$ is peaking in the 1961-1965 and is declining particularly fast after that period.

\section{Empirical analysis}

\subsection{Cointegration analysis for The Netherlands}

In order to gain insight into the time series properties of the variables of our regressions, we have tested whether the series for The Netherlands are co-integrated and have common trends. These tests on the statistical character of the time series are helpful to confront our a priori beliefs on the specification of the regressions, based on economic argumentation, with empirically based evidence. We used the Engle-Granger (EG) method for this. The first step is to 
determine the order of integration of the variables which we did by means of the Augmented Dickey-Fuller (ADF) test. This test on the order of integration shows if the time series used in our analysis are stationary. If a time series is of the type $\mathrm{I}(0)$, it is a stationary series without a trend. In case of $\mathrm{I}(1)$ the time series may contain a trend and the first difference of the series is of the order $\mathrm{I}(0)$ and stationary. In case of I(2) time series contain an element of acceleration (or deceleration) and are made stationary by taking second order differences. The results of this test to determine the order of integration are shown in Table 2.

The table shows that TFP and trade innovations are integrated in the first order. The R\&D stock seems to be integrated in the second order. This would imply that there can be no long-run cointegration (see later) relation between TFP and R\&D and from this empirical perspective, a relationship between R\&D and TFP is hard to establish.

The next step is to see whether a long-run relationship between variables of the order I(1) can be established. The prerequisite for a statistically correct estimation of such long-run relationship is that that trend of these variables is about the same, in the sense that the difference between the weighted trends of these variables is a stationary series. In order to find out about the cointegration between our measure of trade innovations and TFP, we performed the ADF unit root test on the residuals of the static Eq. 3.

$\ln \left(\mathrm{TFP}_{t}\right)=\beta_{0}+\beta_{1} \ln \left(\mathrm{TI}_{t}\right)+\varepsilon_{t}$

The $t$-statistic of this test is -3.54 and the critical value at the 5\% level is -2.95 . This indicates that TFP and trade innovations are indeed co-integrated and that a long-run equilibrium exists. This result strengthens our a priori belief that innovations in the transaction sector can be an important source of productivity growth in trading countries like The Netherlands.

\subsection{Specification}

Most empirical studies on TFP use a simple Cobb-Douglas production function. Determinants of productivity are investigated directly by including additional explanatory variables in a specification which explains production, or in a two step procedure. In the latter method, the first step derives TFP as the unexplained part of a standard production function. The second step explains TFP by additional determinants. Our empirical analysis follows the two step procedure. For the first step we take TFP data from a previous study so that our analysis concentrates on the second step that tries to explain TFP. We do not specify a fully fledged model that encompasses the influence of both product and trade innovations, but just perform a simple time series analysis where we look at the relative explanatory power of $R \& D$ stock and our proxy for trade innovations on TFP. In spite of the outcome of the previous cointegration analysis we adhere to the Cobb-Douglas specification in the sense that we regress the level of TFP with the levels (stocks) of R\&D and TI. In other words we overrule the outcome of the cointegration analysis as our specification assumes that R\&D and TI have the same order of integration. When we would explain TFP by differences in the stock of R\&D and by the level of TI, it would not have any economic interpretation. The fact that we have to overrule the results of the statistical analysis of the (long-run) relationship between the stock of R\&D and TFP in order to obtain a economically plausible result, whereas such overruling was not needed in the case of the (long-run) relationship between TI and TFP, already gives a first indication that TI may be a better determinant for TFP than the stock of R\&D.

Unfortunately our sample period provides us with too little observations to allow a fully fledged error correction specification with a long-run relationship and an error correction mechanism for the short-run relationship. Instead we use two specifications in our analysis which estimate the long-run relationship between the I(1) variables and the short-run relationship between the $\mathrm{I}(0)$ variables separately. The first specification (4) explains the level of TFP by the level of the explanatory variables and represents the long-run relationship.

Here the lagged dependent variable is included as additional explanatory variable. This Koyck-lag represents a partial adjustment mechanism, which characterizes the dynamic response mechanism towards long term equilibrium. Logarithms are taken in order to allow for an elasticity interpretation.

$\ln \left(\mathrm{TFP}_{t}\right)=\beta_{0}+\beta_{1} \ln \left(\mathrm{TFP}_{t-1}\right)+\beta_{2} \ln \left(\mathrm{RD}_{t}\right)+\beta_{3} \ln \left(\mathrm{TI}_{t}\right)+\varepsilon_{t}$

In this specification the coefficient values $\beta_{2}$ and $\beta_{3}$ yield short-run elasticities. Long-run elasticities can be

Table 2 Order of integration

\begin{tabular}{llllllll}
\hline & $\ln (\mathrm{TFP})$ & \multicolumn{3}{c}{$\ln (\mathrm{RD})$} & \multicolumn{3}{c}{$\ln (\mathrm{TI})$} \\
\hline & $\mathrm{I}(0)$ & $\mathrm{I}(1)$ & $\mathrm{I}(0)$ & $\mathrm{I}(1)$ & $\mathrm{I}(2)$ & $\mathrm{I}(0)$ & $\mathrm{I}(1)$ \\
$t$-Statistic & -1.33 & -6.17 & -2.45 & -0.63 & -3.54 & -2.29 & -9.58 \\
Critical value at 5\% & -2.94 & -2.94 & -2.94 & -2.94 & -2.94 & -2.94 & -2.94 \\
Order of integration & & $\mathrm{I}(1)$ & & & $\mathrm{I}(2)$ & & $\mathrm{I}(1)$ \\
\hline
\end{tabular}


calculated by dividing these short-run elasticities by $\left(1-\beta_{1}\right)$.

Our second specification (5) regresses the growth rate of TFP on the growth rates of R\&D and TI. This regression focuses on the short-run relation between technical progress and the two types of innovations considered in this paper. Assuming again that data on $R \& D$ are $I(1)$ and not $I(2)$, this specification regresses stationary time series. In this alternative specification a star indicates the growth rate.

$\mathrm{TFP}_{t}^{*}=\beta_{0}+\beta_{1} \mathrm{R}^{*}{ }_{t}^{*}+\beta_{2} \mathrm{~T}_{t}^{*}+\varepsilon_{t}$

4.3 The contribution of trade innovations and R\&D to productivity

Table 3 shows the results of the empirical investigation of the impact of R\&D and trade innovations on TFP in The Netherlands according to specification (4). Variants 1-3 use the entire sample period (1955-1992) whereas variants 4 and 5 repeat the calculations for variant 3 for two subperiods. These sub-periods are 1952-1970 and 1971-1992, which are chosen because they reflect different patterns of growth of our key variables: Table 1 shows that growth rates are much lower after 1970. The first sub-period can also be seen as a period of prosperous, Keynesian demand driven growth, while stagflation and growth hampered by (oil price) supply shocks characterize the second subperiod.

The results for variants $1-3$ for the entire period show that adjustment of TFP to the stocks of R\&D and TI is rather slow. Coefficient values of about 0.8 suggest a mean adjustment lag of 4 years. When the stocks of R\&D and TI are included separately in the specification (variants 1 and 2) it appears that both variables obtain significant coefficient values. However, the coefficient value for TI is much higher than for R\&D, and its $t$-value is somewhat higher as well. It suggests that in the entire observation period trade innovations carried a larger weight than product and process innovations in determining TFP. Surprisingly the coefficient values become smaller and loose much of their significance when both sources of innovations are included in the specification in variant 3. Apparently both explanatory variables represent part of a general innovative climate where product and process innovations are much linked to trade innovations. Variants 4-5 show that the coefficient values change considerably over the sub-periods. Remarkably the coefficient for the lagged dependent variable becomes smaller suggesting a faster adjustment. In the first sub-period (1955-1970) the influence of TI on TFP is much larger than that of R\&D on TFP. Yet both coefficient values are not significant, like in the estimate for the entire sample period. Both coefficients are positive and significant in the second sub-period. Moreover, according to variant 5, there is no large difference between the influence of R\&D and of TI on TFP in period 1971-1992. It suggests that both types of innovations have become more important for productivity in The Netherlands in this latter sub-period of economic turmoil.

We realize that the above specification poses an endogeneity problem. A higher TFP may bring about more trade innovations because the potential gains of investments in trade innovations can be higher. Moreover, GDP is used to calculate TFP as well as trade innovations. It might cause trade innovations and the error term to be correlated. However, we were unable to find and use an appropriate instrument to correct for simultaneity. Moreover, inclusion of the lagged dependent variable indicates long adjustment lags, whereas estimates using the lagged independent variable gave similar results with respect to the effects of R\&D and TI. Yet we prefer the specification with the lagged dependent variable as partial adjustment seems, from an economic perspective, a more appropriate adjustment mechanism.
Table 3 The contribution of R\&D and trade innovations to TFP in The Netherlands on the long-run

Standard errors are reported in parenthesis

Statistical significance levels at $10 \%, 5 \%$ and $1 \%$ are indicated by $*, * *$ and $* * *$

\begin{tabular}{llllll}
\hline $\begin{array}{l}\text { Dependent variable } \\
\text { Regression }\end{array}$ & $\begin{array}{l}\ln (\mathrm{TFP}) \\
1\end{array}$ & $\begin{array}{l}\ln (\mathrm{TFP}) \\
\ln (\mathrm{TFP})\end{array}$ & $\begin{array}{l}\ln (\mathrm{TFP}) \\
4\end{array}$ & $\begin{array}{l}\ln (\mathrm{TFP}) \\
5\end{array}$ \\
\hline $\ln \left(\mathrm{TFP}_{t-1}\right)$ & $0.865^{* * *}$ & $0.797 * * *$ & $0.809 * * *$ & 0.526 & $0.369^{*}$ \\
& $(0.043)$ & $(0.063)$ & $(0.064)$ & $(0.335)$ & $(0.208)$ \\
$\ln \left({\left.\mathrm{R} \& \mathrm{D}_{t}\right)}^{0.038^{* * *}}\right.$ & & 0.019 & 0.018 & $0.213^{* *}$ \\
& $(0.013)$ & & $(0.020)$ & $(0.055)$ & $(0.088)$ \\
$\ln \left(\mathrm{TI}_{t}\right)$ & & $0.144^{* * *}$ & 0.088 & 0.234 & $0.172^{* *}$ \\
& & $(0.047)$ & $(0.075)$ & $(0.276)$ & $(0.065)$ \\
Intercept & $0.445^{* * *}$ & $0.260^{* * *}$ & $0.376^{* *}$ & 0.999 & $0.769 * * *$ \\
& $(0.135)$ & $(0.082)$ & $(0.147)$ & $(0.770)$ & $(0.248)$ \\
Estimator & OLS & OLS & OLS & OLS & OLS \\
Period & $1955-1992$ & $1955-1992$ & $1955-1992$ & $1955-1970$ & $1971-1992$ \\
Observations & 38 & 38 & 38 & 16 & 22 \\
$R^{2}$ & 0.995 & 0.995 & 0.995 & 0.955 & 0.990 \\
\hline
\end{tabular}


Table 4 The contribution of $\mathrm{R} \& \mathrm{D}$ growth and growth of trade innovations to TFP growth in The Netherlands on the shortrun

Standard errors are reported in
parenthesis
Statistical significance levels at
$10 \%, 5 \%$ and $1 \%$ are indicated
by $*, * *$ and $* * *$

Table 4 presents the estimation results for specification (5) that uses growth rates instead of levels, focussing on the short-run relationship between innovations and productivity growth. The first three columns show the results for the entire period while the other two columns show the results for the same two sub-periods that were also used in the previous specification.

According to variants 1 and 3 of this specification the growth of the stock of $R \& D$ does not seem to have a statistically significant effect on the growth of TFP. The growth of trade innovations, however, is significant at the $5 \%$ level in variant 2 and at the $10 \%$ level in variant 3 . The growth of trade innovations explains about $13.7 \%$ of the variation in TFP while the growth of R\&D explains less than 5\% according to these results. Again these results suggest that in the entire period, trade innovations have been more important than process and product innovations for productivity growth in The Netherlands.

The last two columns of Table 4 show the results for the same specification used in variant 3 but for the two subperiods. These results show that in the short-run specification, $R \& D$ and trade innovations are also much better at explaining TFP in the second sub-period than in the first sub-period. In the 1955-1970 period the explanatory power of the regressions is less than $10 \%$ and none of the variables are statistically significant at the $10 \%$ level. In the 1971-1992 period the R\&D growth is significant at the $10 \%$ level and the growth of trade innovations is significant at the $5 \%$ level. Here the explanatory power increases to about $35 \%$, which is a reasonably good result for a specification in growth rates.

\section{Conclusions}

With respect to the three research questions in the introduction, the empirical analysis of this paper provides the following answers: (i) trade innovations contribute considerably to productivity in The Netherlands; (ii) in the reference period trade innovations seem to contribute at least as much to productivity as investments in R\&D in The Netherlands; (iii) these conclusions suggest that innovations lowering transaction costs should be incorporated in the Lisbon Strategy, or at least that the exclusive focus of the Lisbon criteria on investing $3 \%$ of the GDP on R\&D is unwarranted for The Netherlands.

We acknowledge that this paper provides only a first attempt to separate the influence of product and trade innovations on productivity. It leaves much scope for future research. First, the proxy that is used to measure transaction costs, measures the effect of lowering transaction costs and not the expenditures on innovations lowering these costs. Here an adequate data set with longitudinal data at the plant level is warranted. However, a strict separation between $R \& D$ and trade innovations will be difficult to make, because R\&D do partially measure innovations lowering transaction costs. It may be useful to make a further breakdown into various types of investments which enhance the division of labour and productivity. Spillovers between these different types of knowledge investments will complicate the analysis but can also give an indication for the need of government intervention in case of externalities.

Secondly, the existence of reverse causality between TFP and trade innovations can influence the results. This reverse causality, or more precisely the proposition that the causality runs from productivity to trade, is a much discussed issue in the literature. It is, in fact, part of a more general discussion on the determinants of the 'make or buy' decision, where transaction costs and R\&D spillovers play an important role (see Gattai 2005; Lumenga-Neso et al. 2005). In our view there is, from the transaction costs perspective, reason to assume that causality runs (also) from the innovative skills that reduce transaction costs to productivity.

Thirdly the analysis reported here only considers the impact of R\&D and trade innovations in The Netherlands, and only for a historical reference period. A further research question is whether major differences exist 
between the impact of R\&D and trade innovations on TFP among countries. A preliminary analysis in the project of this paper indeed revealed such differences for a number of OECD countries, albeit that in a simple regression not much significant coefficients were obtained and that the sizes and signs of the coefficients were difficult to interpret. A first conclusion therefore is that the 'one size fits all' approach of the Lisbon Strategy and the focus on R\&D expenditures for enhancing growth and the competitive position might not be justified for other OECD countries as well. However, such conclusion warrants a much more sophisticated empirical analysis. It would be interesting to have such analysis focussed upon the structural differences of countries which can be regarded as production based economies, which possibly high levels of technological R\&D, and countries like The Netherlands which are much more (but not solely) oriented towards trade and services in the transaction sector.

Another question for further research regards the impact of these trade innovations on employment, at home and abroad. Up to now the focus is on employment changes and labour market dynamics because of an international rearrangement of jobs in the production sector, including 'production' of services (see the survey by Hoekman and Winters 2005). Not much attention is paid to the transition of workers from the production to the transaction sectors and to the worldwide division of labour in this respect (see however Mitra and Ranjan 2007; Kirkegaard 2007). Future research may deal with these problems and provide more empirical evidence on the contribution of trade innovations to productivity growth.

Acknowledgements We acknowledge useful comments by Dany Jacobs and by referees of this journal on previous versions of the paper.

Open Access This article is distributed under the terms of the Creative Commons Attribution Noncommercial License which permits any noncommercial use, distribution, and reproduction in any medium, provided the original author(s) and source are credited.

\section{References}

Aghion P, Howitt P (1998) Endogenous growth theory. MIT Press, Cambridge

Amable B (2000) International specialisation and growth. Struct Change Econ Dynam 11:413-431. doi:10.1016/S0954-349X (00)00026-6

Arrow KJ (1969) The organization of economic activity: issues pertinent to the choice of market versus nonmarket allocation. In: Joint Economic Committee, The analysis and evaluation of public expenditure: the PPB System, Government Printing Office, Washington DC, pp 59-73

Cameron G (1998) Innovation and growth: a survey of the empirical evidence. Nuffield College, Oxford
Canton EJF (2002) Onderwijs, R\&D en economische groei. CPB Memorandum 24

De Haan M, Van Rooijen-Horsten M (2004) Measuring R\&D output and knowledge capital formation in open economies. CBS Discussion Paper 04009. CBS, Voorburg

Den Butter FAG, Wollmer FJ (1992) Endogenising Technical Progress in the Netherlands. Beleidsstudies Technologie Economie 22. Ministerie van Economische Zaken, The Hague

Den Butter FAG, Wollmer FJ (1996) An empirical model for endogenous technology in The Netherlands. Econ Model 13:1540. doi:10.1016/0264-9993(96)01003-6

Dietrich M (1994) Transaction cost economics and beyond: towards a new economics of the firm. Roudledge, London

Gattai V (2005) From the theory of the firm to FDI and internationalisation: a survey. FEEM Working Paper 51

Gelauff GMM, Lejour AM (2006) Five Lisbon highlights: the economic impact of reaching these targets. CPB Document 104. $\mathrm{CPB}$, The Hague

Guellec D, Van Pottlesberghe de le Potterie B (2001) R\&D and productivity growth: panel data analysis of 16 OECD countries. OECD Economic Studies 33. OECD, Paris

Herrendorf B, Teixeira A (2005) How barriers to international trade affect TFP. Rev Econ Dynam 8:866-867. doi:10.1016/j.red. 2005.04.001

Hoekman B, Winters LA (2005) Trade and employment: stylized facts and research findings. World Bank Policy Research Working Paper 3676

Hulten CR (2000) Total factor productivity: a short biography. NBER Working Paper 7471

Jacobs D (1999) Het kennisoffensief, slim concurreren in de kenniseconomie, 2nd edn. Samson, Deventer/Alphen aan de Rijn

Jacobs B, Nahuis R, Tang PJG (2002) Sectoral productivity growth and R\&D spillovers in the Netherlands. De Economist 150:181210. doi:10.1023/A:1015696202835

Kirkegaard JF (2007) Offshoring, outsourcing and production relocation-labour market effects in the OECD countries and developing Asia. Peter G. Peterson Institute for International Economics Working Paper WP07-2

Krugman PR, Obstfeld M (1997) International economics: theory and policy, 4th edn. Addison-Wesley, Reading, MA

Lucas RE (1988) On the mechanics of economic development. J Monetary Econ 22:3-42. doi:10.1016/0304-3932(88)90168-7

Lumenga-Neso O, Olarreaga M, Schiff M (2005) On 'indirect' traderelated R\&D spillovers. Eur Econ Rev 49:1785-1798. doi: 10.1016/j.euroecorev.2004.06.004

Lynch LM (2007) The adoption and diffusion of organizational innovation: evidence from the U.S. economy. IZA Discussion Paper 2819

Minne B (1995) Onderzoek, ontwikkeling en andere immateriële investeringen in Nederland. CPB Research Memorandum 116. $\mathrm{CPB}$, The Hague

Mitra D, Ranjan P (2007) Offshoring and unemployment. IZA Discussion paper 2805

North DC (1991) Institutions, transaction costs, and the rise of merchant empires. In: Tracy JD (ed) The political economy of merchant empires. Cambridge University Press, pp 22-40

North DC (1997) Transaction costs through time. In: Menard C (ed) Transaction cost economics: recent developments. Edward Elgar, Cheltenham, UK, pp 149-160

North DC, Wallis JJ (1982) American governments expenditures: a historical perspective. Am Econ Rev 72:336-340

North DC, Wallis JJ (1986) Measuring the transaction sector in the American economy. In: Engerman SL, Gallman RE (eds), Long term factors in American economic growth, University of Chicago Press, Chicago, pp 95-161 
North DC, Wallis JJ (1994) Integrating institutional change and technical change in economic history: a transaction cost approach. J Inst Theor Econ 150:609-624

OECD (2002) Frascati manual: proposed standard practice for surveys on research and experimental development. OECD

Romer PM (1986) Increasing returns and long-run growth. J Polit Econ 94:1002-1037. doi:10.1086/261420

Solow RM (1957) Technical change and the aggregate production function. Rev Econ Stat 39:312-320. doi:10.2307/1926047

Timmer M, Ypma G, Van Ark B (2003) IT in the European Union: driving productivity divergence? GGDC Research Memorandum GD-67

Tinbergen J (1942) Zur theorie des langfristigen wirtschaftsentwicklung. Weltwirtsschaftliches Archiv 55:511-549

Trefler D (1995) The case of missing trade and other mysteries. Am Econ Rev 85:1029-1046
Van Ark B, De Jong H (1996) Accounting for economic growth in the Netherlands since 1913. GGDC Research Memorandum GD-26

Van Ark B, Melka J, Mulder N, Timmer MP, Ypma G (2002) ICT investment and growth accounts for the European Union, 1980 2000. GGDC Research Memorandum GD-60

Van Dalen HP, Van Vuuren AP (2005) Greasing the wheels of trade. De Economist 153:139-165. doi:10.1007/s10645-005-2933-4

Wang N (2003) Measuring transaction costs: an incomplete survey. Ronald Coase Institute Working Paper 2

Williamson OE (1985) The economic institutions of capitalism. Free Press, New York

WRR (Scientific Council for Government Policy) (2003) Nederland handelsland, het perspectief van de transactiekosten. Reports to the Government 66. Sdu Publishers, The Hague 